\title{
Institutional change in varieties of capitalism
}

\author{
Peter A. Hall ${ }^{1}$ and Kathleen Thelen ${ }^{2}$ \\ ${ }^{1}$ Minda de Gunzburg Center for European Studies, Harvard University, Cambridge, MA, USA; \\ ${ }^{2}$ Department of Political Science, Northwestern University, Evanston, IL, USA \\ Correspondence: phal/@fas.harvard.edu
}

\begin{abstract}
Contemporary approaches to varieties to capitalism are often criticized for neglecting issues of institutional change. This paper develops an approach to institutional change more extended than the one provided in Hall and Soskice (in Varieties of Capitalism: The Institutional Foundations of Comparative Advantage, Oxford, Oxford University Press, 2001) but congruent with its varieties-ofcapitalism perspective. It begins by outlining an approach to institutional stability, which suggests that the persistence of institutions depends not only on their aggregate welfare effects but also on the distributive benefits that they provide to the underlying social or political coalitions; and not only on the Paretooptimal quality of such equilibria but also on continuous processes of mobilization through which the actors test the limits of the existing institutions. It then develops an analysis of institutional change that emphasizes the ways in which defection, reinterpretation and reform emerge out of such contestation and assesses the accuracy of this account against recent developments in the political economies of Europe. The paper concludes by outlining the implications of this perspective for contemporary analyses of liberalization in the political economy.
\end{abstract}

Keywords: capitalism; varieties of; economic reform; Europe; globalization; institutional change; institutions

JEL classification: NO economic history

\section{Introduction}

Comparative political economists have become deeply interested in processes of institutional change, especially those taking place in response to the opening of world markets associated with 'globalization' (Pierson, 2001; Djelic and Quack, 2003; Rieger and Leibfried, 2003; Campbell, 2004). They are asking a number of questions: When do the institutions of the political economy change? What factors drive the change? Are the changes in the international economy enforcing institutional convergence on the developed economies? 
We take up these issues with reference to one of the more influential frameworks devised to explain national differences in economic performance and policy, namely the 'varieties of capitalism' perspective now employed by a substantial number of scholars (see Hall and Soskice, 2001). Building on the literatures of neo-corporatism and the 'regulation school', this approach applies the new economics of organization to the macroeconomy (Boyer, 1990; Schmitter and Streeck, 1985; Milgrom and Roberts, 1992). It focuses on firms, as actors central to the process of economic adjustment with core competencies that depend on the quality of the relations that they develop with other actors, including producer groups, employees and other firms. Those relationships depend, in turn, on the institutional support provided for them in the political economy. Although the perspective acknowledges that these relationships can take on a wide range of forms, it emphasizes the distinction between liberal market economies, where firms rely heavily on competitive markets to coordinate their endeavours, and coordinated market economies, where more endeavours are coordinated strategically. These different modes of coordination are said to confer comparative institutional advantages that mediate national responses to globalization. They rest on institutional complementarities that allow arrangements in one sphere of the political economy to enhance the results secured in others. The framework provides distinctive perspectives on many of the issues raised by globalization.

However, questions have been raised about the adequacy of the varieties-ofcapitalism perspective for understanding institutional change. Some argue that this approach is overly static and its distinction between liberal and coordinated market economies outmoded by the liberalization of the world's economies. Others read into it an overweening functionalism that explains institutional change by reference to its macroeconomic effects, and suggest that the approach neglects the social or political dimensions of institutional change. ${ }^{1}$ These critiques raise important issues that go well beyond the Hall and Soskice (2001) volume. The varieties-of-capitalism approach offers fresh and intriguing insights into differences among the developed economies, but it can hardly be considered viable if it cannot also address processes of institutional change. Many of the criticisms suggest that the equilibrium elements of the new economics of organization analysis are inimical to dynamic analysis and that rationalist approaches understate the chaotic quality of institutional change or the contribution unintended consequences make to it. These concerns have significance for the analysis of institutional change more generally.

\footnotetext{
${ }^{1}$ For relevant critiques see Howell (2003), Goodin (2003), Watson (2003), Blyth (2003), as well as those collected in Coates (2005) and Stato e Mercato, 69 (December 2003).
} 
The objective of this paper is to address these issues by elaborating an account of institutional change more extended than the one provided in the study by Hall and Soskice (2001), but congruent with its varieties-of-capitalism perspective. Our claim is that this perspective embodies a sophisticated understanding of institutional change that is eminently political and useful for analysing contemporary developments in the advanced political economies. We show that the equilibrium aspects of this approach are not incompatible with dynamic views of the political economy and explain why rationalist approaches to the political economy need not imply a barren functionalism.

We begin by reviewing some basic tenets of the varieties-of-capitalism approach that underpin cross-national comparisons in order to show that they can inform the analysis of change as well. Based on these tenets, we develop a series of propositions concerning the sources of institutional stability, which we subsequently use to develop contentions about institutional change. Although our principal objective is to outline a theoretical perspective, we provide some preliminary substantiation for its propositions with reference to recent developments in Germany and other coordinated economies, since these are key cases for analysts of change in the political economy. We close by drawing some general conclusions about the trajectory of the European economies today.

\section{The institutional and theoretical terrain}

In this paper, we conceptualize institutions as sets of regularized practices with a rule-like quality in the sense that the actors expect the practices to be observed; and which, in some but not all, cases are supported by formal sanctions. They can range from regulations backed by the force of law or organizational procedure, such as the rules that apply when a worker is laid off, to more informal practices that have a conventional character, such as the expectation that firms will offer a certain number of apprenticeships. ${ }^{2}$ In some cases, macroinstitutions, such as the 'vocational training system', are composed of many component rules and practices that are themselves institutions.

Compared with alternative perspectives, several features of the varietiesof-capitalism approach to institutions are distinctive. First, as a firm-centric and broadly rationalist approach, it conceptualizes the political economy as a terrain peopled with entrepreneurial actors seeking to advance their interests as

\footnotetext{
${ }^{2}$ While analytically distinct, it is worth noting that the more formal and the more informal or conventional dimensions of institutions are often linked. For example, the convention that large firms supply apprenticeship slots is supported, albeit at slight remove, by a number of formal institutions-e.g. compulsory membership in employer chambers, strong unions pushing firms up-market, and relatively centralized wage bargaining institutions that compress wages and allow firms to earn rents on training.
} 
they construe them, constrained by the existing rules and institutions but also looking for ways to make institutions work for them. Although some institutions rely on sanctions for their operation, the varieties-of-capitalism approach moves away from a view of institutions purely as factors that constrain action towards one that sees them also as resources, providing opportunities for particular types of action, and especially for collective action (see Hall, 1998).

Second, the varieties of capitalism framework emphasizes that the political economy is replete with a multiplicity of institutions, many of which are nested inside others. Some can serve as functional substitutes for other institutions, at least for some purposes. ${ }^{3}$ Thus, any strategy adopted by a firm or other actor is likely to be conditioned, not by one, but by a number of institutions. Emphasizing institutional interaction effects, the varieties-of-capitalism approach argues that firm strategies are conditioned simultaneously by multiple institutions, often in different spheres of the political economy (Hall and Soskice, 2001, pp. 21-36).

There are important points of tangency between this perspective and some other well-known approaches to institutions. From the 'logic of appropriateness' approach favoured by some new institutionalists, this perspective accepts the point that institutions may sometimes influence action because they define behaviour seen as appropriate to the endeavour at hand from the perspective of a particular cultural worldview (March and Olsen, 1989; Dobbin, 1994). From the 'institutions as equilibrium' approach advanced by Calvert $(1995 a, b)$ and others, it accepts the observation that the stability of a particular pattern of strategic interaction often rests on the absence of Pareto-improving alternatives apparent to the actors under current conditions. Although often presented as polar opposites, we do not regard these perspectives as mutually exclusive in a real world that contains many motives for and patterns of behaviour.

However, neither of these approaches fully conveys the institutions as resources' element of our perspective and, if carried to extremes, both overstate the degree to which any one institution determines the action. To say that an institution specifies patterns of behaviour seen as appropriate to the culture should not be taken to imply that all or even most in that culture adhere slavishly to it. There is always room, and often reason, to be critical of what is deemed 'appropriate'. Similarly, although the mutual benefits of strategic interaction may render an institution more stable, this observation says only a little about how institutions are sustained, because it ignores the omnipresent processes of search and negotiation whereby entrepreneurial actors look for alternative ways

\footnotetext{
${ }^{3}$ In a powerful analysis, Streeck (1991) has described this last feature as one that supplies 'redundant capacities' to actors. As he notes, some of these capacities are more available in some places and for some purposes than others.
} 
in which to advance their interests (Knight, 1995). There is more intrinsic openness to the institutional arena than these two perspectives imply.

\section{Institutional stability as a political problem}

Any analysis of how institutions change should begin from a conception of how institutions are sustained during periods when they remain stable. As noted above, the core theoretical pillars that distinguish the varieties-of-capitalism framework from many alternatives are: (i) it puts employer interests at the centre of analysis, and (ii) it draws attention specifically to the institutions that support either market or strategic coordination among firms and between them and other actors. These two theoretical claims generate a specific set of propositions about institutional stability.

First, while the emphasis on employer interests does not imply that other actors (labour, governments) are unimportant, it underscores a crucial assumption, namely, that the institutions and practices of capitalist political economies can rarely be sustained over time without the active support of at least some powerful segments of capital (see, especially, Swenson, 2002). Moreover, as we have noted, the varieties-of-capitalism framework holds that most institutions in the political economy rest not on practices of passive rule-following by firms, but on a more active process in which entrepreneurial actors seek to advance their interests, including in contexts of strategic interaction where institutions can improve the well-being of those who participate in them by resolving collective action dilemmas. Such a view belies any simple notions of 'institutional inertia' and implies a relatively loose coupling between self-interest and institutions.

This loose coupling means that a good deal of politics surrounds institutional stability. From the broadly rationalist perspective we adopt here, the durability of an institution can rest substantially, if rarely wholly, on how well it serves the interests of the relevant actors. Where an institution fails to serve those interests well, it becomes fragile and susceptible to defection from its rules. But actors' calculations about whether an institutional practice serves their interests are complex ones, dependent on a range of considerations. They entail balancing the multiple interests that one single actor has in a potential course of action, along with time discounts and competing evaluations about the effects of one's actions (Hall, 2005).

In the context of this politics, the varieties-of-capitalism perspective draws attention to several factors that can militate in favour of the stability of institutions. One is the presence of institutional interaction. As we have noted, the strategies followed by an actor, such as a firm, and the benefits to be expected from the use of these strategies are usually conditional on the presence of a 
number of other institutions. Many German firms would perhaps be more willing to withdraw from the institutions that coordinate wage bargaining if they did not also face powerful German unions or operate particular types of production regimes. ${ }^{4}$ Where the benefits of changing one institution are likely to be realized only when a substantial number of other institutions are also transformed, that institution should be more stable. Conversely, where there are alternative institutional means available for accomplishing a task, a firm's interests may bind it less tightly to one institution.

Considerations about the ease with which alternative institutions can be constructed also condition the judgements actors make about whether to adhere to an existing institution. Because institutions are collective constructs, it can be difficult to replace one with another. In a few cases, an alternative can be secured by fiat: the Swedish government shifted drivers from the left- to the right-hand side of the road in one fell swoop. But, in many instances, as Culpepper (2003) shows, it can be difficult to persuade actors to coordinate on new ways of doing things, even when there are reasons to think they might be Pareto-improving. Before a new institution is established, one cannot prove it will deliver benefits, and the relevant actors cannot be sure of the behaviour of others on whom its efficacy may depend. The presence of such uncertainties is a crucial factor underpinning institutional stability (Shepsle, 1986).

Thus, the availability of meta-institutions for deliberation and rule-making can be crucial to the stability of existing institutions and to the prospects for reform (Hall and Soskice, 2001, pp. 10-12). When the world throws up shocks that unsettle the benefits flowing from the existing institutions, deliberative forums facilitate the re-equilibration of cooperative endeavour, by allowing for (i) 'diagnosis', where the issue is to agree on the cause-and-effect relations generating the problem and pertinent to the solution, and for (ii) 'agreement on distributive justice', where the issue is to apportion the risks and benefits that can flow unequally from cooperation.

However, if daunted, actors are not altogether deterred by uncertainty. The result is a politics of institutional stability. Actors are generally engaged in a continuous reassessment of their own scope for action and the intentions of those with whom they are interacting. They need to be reassured that existing institutions continue to serve their interests and that better alternatives are not available. While some actors probe the outer limits of existing arrangements, others try to defend these institutions by assuring others that they are better than the available alternatives. One feature of this politics is continuous experimentation, as the relevant actors test the bounds of what others will deem acceptable

\footnotetext{
${ }^{4}$ This is confirmed by studies that show a strong correlation between membership in employers associations and union presence at the sectoral level in Germany.
} 
behaviour; seek new information about their partners; assess the effects of alternative courses of action; and consider how severely defection from institutionally sanctioned patterns of behaviour will be punished. For some actors at some times, of course, institutional stability might depend on habit. But, in the political economy, it more often depends on a stream of action that is political in the sense that it entails conflict designed to test the limits of cooperative arrangements and of the processes of mobilization that bring other actors in line with those arrangements (Thelen, 2001, pp. 73 ff.; Hall, 1994).

This brings us to the second pillar of the varieties-of-capitalism approach and its implications for the analysis of stability and change. The approach emphasizes two distinctive ideal-typical patterns of coordination among firms and other actors in the political economy (market coordination and strategic coordination). However, it follows from what we have just said that our perspective calls for some revision in the way in which 'coordination' is construed. In game-theoretic analyses, 'coordination' is sometimes seen as a pattern of behaviour that arises relatively spontaneously, when the opportunity appears among actors who are viewed as contractors. ${ }^{5}$ Coordination is said to follow directly from the presence of supportive institutions. In contrast, from our perspective, the achievement of coordination appears as a political problem. Coordination is not easily secured and rarely follows automatically from the presence of certain institutions. Instead, active support for a specific mode of coordination must be mobilized on a relatively continuous basis from actors who are conscious of the limitations as well as the advantages of any particular course of action. Achieving and maintaining coordination usually also involves the exercise of power, because forging and maintaining particular institutional arrangements creates winners and losers, notably on both sides of the class divide (Moe, 2005; Swenson, 2002; Gruber, 2000; Offe and Wiesenthal, 1986).

Here again, some factors militate in favour of continuity in the institutional landscape. If institutions do not simply resolve collective action dilemmas, but also contribute to the balance of power found in many parts of the political economy, then we can expect the feedback effects of existing institutions to work to the disadvantage of an institution's challengers (Pierson, 1993, 1994). If power relations in a cooperative context turn, in part, on the relative opportunity costs to each side of failing to cooperate, as Knight (1992) has argued, those costs depend on other institutional practices in which the actors are imbricated which may not be immediately susceptible to change. When deciding whether to bargain cooperatively with unions, for instance, employers are influenced by other institutions, such as the works councils they face, the work practices and

\footnotetext{
${ }^{5}$ Bates (1988) and Knight (1992) have drawn attention to this problem.
} 
production regimes they have evolved, and a range of institutions affecting the costs a strike or lock-out would impose on them.

This outline of the politics of stability speaks to one of the principal criticisms levelled at the varieties-of-capitalism perspective, namely, that it adopts an overly functionalist approach to the problem of institutional change (cf. Crouch, 2005; Streeck, 2005). We can see what it borrows from functionalist approaches and where it rejects them. Our perspective shares the functionalist premise that the support that groups provide for an institution is motivated, to some extent, by the benefits the institution provides, flowing from the functions it performs. However, the perspective differs from functionalist accounts in two key respects.

First, we do not assume that support for an institution derives primarily from the contribution it makes to aggregate economic welfare. Varieties-of-capitalism analysts devote a good deal of attention to explaining how the institutions of the political economy contribute to national well-being. But they do not generally claim that the existence of an institution depends on that contribution. Institutional politics as we understand it turns, not on issues of aggregate welfare, but on the actions of self-interested actors seeking better outcomes for themselves or the groups they represent (Hall and Soskice, 2001, pp. 57-58).

Second, in contrast to some functionalist analyses, we think it dangerous to assume that the institutions of the political economy were originally created to serve the interests they advance at much later periods of time. German employers, for instance, expressed vociferous opposition to the 1950s legislation that enhanced labour's rights on the shop floor (Hoepner, 2003). However, once those institutions were in place, employers organized production strategies and a range of ancillary practices around them, aiming at high-priced, high-quality production (Streeck, 1992). As a result, most large manufacturing firms support works councils, because their market and production strategies rely on them. In this as in many other such instances, the institutions of the political economy are instruments that actors gradually adapt to their purposes and in which they become invested only after they have accommodated their practices to them (Thelen, 2004). ${ }^{6}$ Thus, the current effects of an institution may help to explain contemporary support for it but can explain the origins of an institution only rarely.

In sum, although some see the varieties-of-capitalism approach as insufficiently political because it focuses on the ways firms coordinate their endeavours construed in equilibrium terms, it deploys an understanding of institutions that anticipates a lively politics, marked by experimentation, negotiation and conflict, even in cases of institutional stability. As Thelen (2001) argued, this approach has

\footnotetext{
${ }^{6}$ As Streeck (2004) notes, even institutional complementarities are therefore often 'discovered' rather than designed.
} 
always rejected the notion that institutions are automatically stable, even when they are Pareto-improving, and it associates the maintenance of equilibrium outcomes with important political dynamics.

\section{Institutional change in the political economy}

Our understanding of institutional change follows directly from this perspective on institutional stability. Because political economies are full of entrepreneurial actors interested in improving their positions, existing institutions are bound to come under pressure. Institutional equilibria change as developments shift the material situation, power and self-understandings of the actors. Thus, Hall and Soskice (2001, p. 54) argued that institutional change will be a regular feature of both liberal and coordinated market economies. The key issues are: what precipitates change, which actors are central to it, how will it occur and how should we interpret the results?

\subsection{The impetus for institutional change}

There is no doubt that events in the international political economy are important stimuli for contemporary institutional change. Among the OECD countries, such developments include the growing weight of the service sector in employment and falling barriers to trade or communication that intensify international competition and open up opportunities for sales or production elsewhere in the world. The liberalizing initiatives of the European Union, the collapse of Communism and the reunification of Germany have been of special importance to Europe. These developments have shifted the opportunity structures and returns to existing institutions for many firms and workers, inspiring institutional ferment in Europe, and some analyses treat the problem of institutional change as if the impetus were invariably exogenous to the institutions themselves (cf. Frieden and Rogowski, 1996).

As others have noted, however, many institutional changes in the political economies of Europe have been inspired by unanticipated effects flowing from existing institutions (Thelen, 2004; Thelen and van Wijnbergen, 2003; Greif and Laitin, 2005). The case of solidaristic wage bargaining in Sweden is a wellknown example (see, especially, Pontusson and Swenson, 1996). In the 1930s, Swedish employers pressed for centralized bargaining arrangements in order to link wages in the sheltered sectors to those bargained for in the export sectors. But they did not anticipate that centralized bargaining would also become a vehicle for compressing differentials between the wages of skilled and unskilled workers. Over time, centralized bargaining strengthened the position of unskilled workers, whose interests could be pooled across all industries in a way that had 
not been possible under sectoral bargaining, and became the vehicle for political exchange with a strong social democratic government. As Sweden's unskilled workers used their strength to narrow differentials with skilled workers, however, they undermined the capacity of employers to recruit and deploy skilled labour. By the 1980s, concerns about this issue were grave enough to lead the export sectors to pull out of centralized bargaining arrangements, thereby modifying the institution they had originally created.

We see a similar dynamic of endogenously generated change in the German economy, where firms in declining industries, such as coal and steel, took advantage of early retirement policies to resolve structural crises during the 1950s and 1960s. As these strategies proliferated in unanticipated ways in the 1970s and beyond, they fuelled massive increases in non-wage labour costs (Manow and Seils, 2000). Although effective at facilitating orderly workforce reductions in the 1980s and 1990s, these retirement practices had a deadening effect on job creation and imposed heavy burdens on social insurance funds. The effect was to spark not only revisions to the early retirement regime, but also broader pressures for labour market reform.

In short, the history of change in the European political economies should not be written as if it were entirely a series of responses to external shocks. The challenge facing analysts is to see it as a process partly endogenous to the character of the institutions developed in each nation and driven by the unintended consequences that flow from those institutions.

\subsection{Multiple agents of adjustment}

One of the notable features of the varieties-of-capitalism approach is its insistence that there are multiple agents of adjustment in the political economy. Globalization is often presented as a contest between states and market forces (cf. Cable, 1995), and there is no denying that the decisions governments take in response to international challenges play a key role in the institutional development of the political economy. In such contexts, as Streeck (2004) has observed, governments come closest to being architectonic actors: on the regulations they promulgate depend many other institutions. However, the varieties-of-capitalism perspective insists that firms can be equally important agents of national adjustment. They cannot always construct new collective institutions without help from governments, but shifts in firm strategy can erode the viability of some institutions and strengthen others. Moreover, firms are even more sensitive than governments to shifts in the economy, because their survival is at stake. A good deal of the process of institutional adjustment in the developed economies can be understood as a pas de deux between firms and governments in which each responds to different pressures but has to cope with the moves made by the other side. 
Recent analyses by Culpepper (2006) and O’Sullivan (2007) of changes in the structure of French financial markets are revealing. Although those shifts began with government initiatives to privatize national enterprises and expand the ambit of French equity markets, the traditional networks binding French business to the state were unwound only when key firms took the initiative to dissolve their core shareholdings in the newly privatized enterprises and to seek foreign acquisitions and investors. Much of the impetus for their strategies derived from the opening of international markets made possible by agreements the French governments signed, but those strategies were driven by new market pressures and opportunities. Large French firms realized they would prosper only if they secured global market share, and higher stock prices became a major asset in the stock swaps used to secure new acquisitions. Thus, French companies took a series of initiatives to solidify their market positions, and the government obliged with congenial regulatory reforms (Tiberghien, 2002).

As important as state policy is to how markets are structured and operate, governments typically do not have the luxury of responding to economic developments on a tabula rasa. In many cases, they have to react to corporate strategies that are shifting even more rapidly in response to those developments. Changes in rules often follow the accumulation of 'deviant' behaviour, with a view to bringing formal rules or legal regimes back into alignment with behaviour (Streeck and Thelen, 2005, pp. 15-16). By placing employers at the centre of analysis, the varieties-of-capitalism framework contextualizes the analysis of government reform, drawing attention to the transformative potential of shifting firm strategies. ${ }^{7}$

\subsection{Institutional change and the politics of coordination}

As William Sewell has emphasized recently, tumult is a permanent feature of capitalism - as fortunes are made and lost, firms are founded and fail, workers are hired, trained and fired, as technology transforms production and as whole industries, regions and countries prosper or decline (Sewell, 2008). In a context whose defining feature is change, we need a theory to tell us which changes exactly we should be noting-in other words, which changes are likely to be consequential for the efficacy of the economy and related social outcomes.

The varieties-of-capitalism framework provides an answer, suggesting that the changes that should command our attention are those affecting the capacities of firms to coordinate strategically. As noted above, the varieties of capitalism perspective takes a broad view of institutions that does not fixate on formal

\footnotetext{
${ }^{7}$ Organized labor is another actor whose strategies, including those aimed at maintaining coordination across a diverse membership, are obviously important.
} 
'parchment' rules. Indeed, this perspective insists that it is essential to distinguish between the formal institutional arrangements and the economic equilibria those institutions support through their impact on the incentives and strategies of actors, such as firms and workers. Many formal institutional changes-even quite dramatic ones-are largely inconsequential with respect to the extent and type of employer coordination achieved under them, and stability in formal institutional arrangements does not in itself imply the absence of potentially consequential shifts in coordination in the political economy. Let us pursue each of these somewhat counterintuitive points.

First, as an empirical matter, it is clear that specific types of coordination (whether market or strategic) can be sustained throughout many changes in the formal institutional infrastructure governing a political economy. The two broad families of political economies identified by the varieties of capitalism approach have deep roots in history (Iversen and Soskice, 2007). Over the past century, for example, strategic coordination in Sweden has survived massive changes in the social and political context, including democratization and the transition from agriculture to industry to services. Thelen (2004) documents many significant revisions to the rules governing Germany's system of coordinated training, as it was adapted over a 100-year time period to incorporate new actors and address new technological and market conditions. A major message of her study was that significant revisions to formal institutional arrangements may not only be consistent with continued coordination, but are often necessary to sustain it (see also Hacker, 2005).

Conversely, formal institutional stability is no guarantee of continued coordination. While many analysts of institutional change focus their attention on major legislative initiatives, such as Margaret Thatcher's reforms to industrial relations or Gerhard Schröder's reform of corporate taxation, the framework we have outlined suggests that equally significant changes may transpire in more subtle ways, under the surface of formal institutional stability. In such cases, stability in formal institutional arrangements masks important shifts in the extent and type of coordination achieved under them. Among the developments that may be most consequential for coordination, we draw attention to processes of defection and re-interpretation. ${ }^{8}$

We borrow the term 'defection' from game theory, where it refers to strategies that deviate from the behaviours associated with a cooperative outcome, and use

\footnotetext{
${ }^{8}$ These are not exhaustive of the modes of change that can be observed in contemporary political economies, and a somewhat broader (though, again, not exhaustive) inventory is discussed in Streeck and Thelen (2005). Defection is the mechanism that defines the mode of change that Streeck and Thelen call institutional 'displacement', and their mode of 'conversion' features reinterpretation as the main mechanism of change (p. 31).
} 
it for cases in which actors who have been following the practices prescribed by an institution stop doing so. Although less eye-catching than legislative reform, this is an important route to institutional change in the political economy. Recent developments in the German metalworking sector provide a good example (see Thelen and Kume, 1999; Thelen, 2000). For the past 50 years, German collective bargaining has taken the form of pattern bargaining led informally by the metalworking sector. Over the course of the 1970s and 1980s, however, a growing number of small firms opted out of membership in the employer associations that organize this industry. Since collective bargaining coverage relies not on union membership, but on whether a firm is a member of the employer associations, these defections have reduced bargaining coverage. The resulting erosion in bargaining has seriously compromised coordination in industrial relations despite the fact that the formal institutional apparatus for negotiation itself remains intact.

Another route to institutional change that often lies beneath the radar of many other analytic approaches is based on what we call 'reinterpretation'. In these instances, the actors associated with an institution gradually change their interpretation of its rules, and thus its practices, without defecting from or dismantling the formal institution itself. In some cases, this occurs when the courts reinterpret a legal or regulatory regime. In others, it involves the gradual acceptance of practices that would not formerly have been seen as congruent with the formal institution. In comparison with overt efforts to revise or abolish that institution, the process of reinterpretation shifts the existing practices in piecemeal fashion from below (Aoki, 2001; Evans, 2005; Streeck and Thelen, 2005).

Recent developments in German collective bargaining encompass many instances of reinterpretation, as employers and workers attempt to bend the existing practices to suit their interests, without formally abolishing them. A good example lies in skirmishes over the meaning of a core provision in German labour law known as the 'favourability principle' (Günstigkeitsprinzip; Rehder, 2006). This principle stipulates that certain issues normally reserved for collective bargaining at the industry level can be decided at the local level, in bargaining between works councils and individual employers, provided that the outcome operates 'to the advantage of the worker'. Thus, firms can pay wages in excess of the industry rate, but they cannot demand concession bargaining. In recent years, however, employers began to try to take advantage of an ambiguity in the meaning of 'favourability' (Günstigkeit) to justify local employment pacts that offer workers greater job security in return for lower wages. Their argument was that anything offering greater job security in a context of high unemployment operates 'in favour of the worker' ('zu Gunsten des Arbeitnehmers'). Although that particular practice has so far been deemed illegal by the courts, these sorts of efforts to reinterpret the rules that enshrine a particular division of labour in 
collective bargaining have been a regular feature of German industrial relations. In 1984, such efforts led to plant-level agreements on working hours, and others continue to extend the space for work council bargaining on a range of issues (Thelen, 1991; Hassel and Williamson, 2004).

Processes such as these can act as shock absorbers in the face of new economic developments, bringing an elasticity to the institutions of the political economy that analyses focused on formal rules sometimes miss. A significant flexibilization of the German bargaining system has been accomplished without much rewriting of the formal rules, through successive (and successively expansive) interpretations of the scope for bargaining at the local level in response to the market conditions faced by individual firms. These are cases in which the 'rules' conventionally associated with an institution are reinterpreted, often informally, to accommodate new diversities in the interests of the actors associated with it. Moreover, this avenue poses fewer obstacles than might confront reformers if they were to launch a frontal assault on the formal arrangements. Changes can be sought quietly, for example, through the courts, avoiding noisy legislative battles that are sure to mobilize the opposition. ${ }^{9}$ They can be sold as a way to 'fix' problems with the existing arrangements sustaining coordination, thereby offering opportunities to forge coalitions with those who might resist an institution's dismantling but be more than happy to cooperate in 'clarifying' its rules. In short, these forms of elasticity may be important to the survival of strategic coordination, even though they entail changes to the practices associated with a formal set of institutions and some of their substantive outcomes.

\subsection{Governmental reform and the politics of coordination}

Of course, the more visible route to institutional change is through processes of reform, which we define as institutional change explicitly mandated or endorsed by governments. We see this form of institutional change as a process built on coalitional politics, in which segments of capital are usually pivotal. The principal challenge facing analysts, therefore, is to identify the coalitions of social or political actors that provide the support for a change in regulations or policy regimes and the factors motivating their support. The implication of this perspective is that institutional reform originates in political compromises among actors, whether producer groups or political parties, diversely motivated in contexts of distributive conflict (Palier, 2005). Thus, there are no guarantees that the process of institutional reform will advance national well-being. If firms decide to support the regulatory regimes that sustain the comparative institutional advantages of the nation, it is because they also underpin the competitive

\footnotetext{
${ }^{9}$ We thank Terry Halliday for emphasizing this point to us.
} 
advantages of the firm. Behind many reform debates lie other conflicts of interest, such as those that divide capital and labour or different types of firms and workers. Institutional change is a process of continuous mutual adjustment inflected by distributive concerns.

However, the varieties-of-capitalism perspective reminds us that the alignments central to these conflicts can be influenced by the character of existing institutions. Firms and other actors do not judge proposals for reform as if the new institutions will operate on a blank slate but in the context of institutions in other spheres of the political economy. Actors' assessments of the costs or benefits of a new set of institutions will hinge on how those institutions fit with strategies into which they have been drawn by virtue of the presence of supportive institutions elsewhere in the economy. Therefore, institutional arrangements in one sphere of the political economy condition the positions that actors take on institutional reform in other spheres.

Swenson's (2002) comparison of pension politics in Sweden and the U.S. provides a nice example of this point. He shows how institutions developed in the arena of industrial relations during the 1930s conditioned the types of pension policies employers were willing to support in the 1950s. Because Sweden's centralized bargaining system kept wage competition in check, it inspired new forms of competition for skilled workers based on the provision of company pensions. As the costs of the latter rose under conditions of full employment, however, employers found this type of competition overly costly and were willing to support a social democratic initiative to institute generous public pensions. In contrast, the Wagner Act of 1935 left wage bargaining in the United States at the company level, fostering a segmentation between low-skill firms operating with low non-wage costs and high-skill firms that used generous company pensions to attract skilled labour. Because each type of firm had interests in the existing pension regime, in the context of segmental industrial relations, there was no broad business constituency for generous public pensions in the United States.

Goyer's (2006, 2007) comparison of reforms to corporate governance in France and Germany identifies a similar dynamic. In response to international economic developments, there was pressure for reform in both countries. But the character of the reforms firms were willing to support in the sphere of corporate governance was influenced, in each country, by the character of institutional arrangements in the sphere of labour relations. Many French firms were willing to accept measures that made hostile takeovers more feasible and corporate restructuring focused on share prices more urgent because they faced works councils and trade unions that were too weak to mount much opposition to restructuring. There, management's room for manoeuvre is substantial. In Germany, in contrast, where powerful works councils and trade unions are institutionally entrenched, managers were receptive to the adoption of international accounting 
standards and measures to strengthen the position of minority shareholders but resisted efforts to expose firms to hostile takeovers, because industrial relations institutions made it more difficult for them to restructure quickly in response to demands for 'shareholder value'.

\section{The implications for varieties of capitalism}

What does this analysis imply about the survival of distinctive varieties of capitalism in Europe and the trajectories of change in its political economies? The magnitude of the challenges should not be minimized. Over the past decade, Europe's largest economies have suffered from low rates of growth and high levels of unemployment. Aging populations burden many welfare states, and the rise of the service sector has called into question economic models attuned to the demands of industrial capitalism (Iversen and Wren, 1998). In such contexts, there is bound to be institutional change.

\subsection{Beyond liberalization}

However, the terms of contemporary debate about institutional change are manifestly inadequate for the task of assessing the impact of such changes. Many analysts (e.g. Streeck, 2008; Glyn, 2006; Howell, 2003; Coates, 2005) ask whether the developed economies are 'liberalizing' and subsume under that label a wide spectrum of initiatives, including efforts to decentralize collective bargaining, neutralize unions, dismantle tripartism, privatize industry, cut back social benefits, reduce employment protection, promote equity investments, encourage part-time employment and lower minimum wages. Many of these measures reinforce the role of markets in the allocation of resources. But, for those interested in the impact of institutional reform on broad patterns of coordination, the crudeness of this category-'liberalization'-obscures more than it illuminates. It suffers from three prominent limitations.

First, liberalization is a multidimensional process. The types of initiatives we have just listed need not accompany one another and often do not. Denmark has made major cuts to unemployment benefits even as it shored up tripartism and strengthened unions. France has encouraged part-time work without cutting its minimum wage or reducing employment protections for regular fulltime workers. To what extent these measures tend to occur together is an object for inquiry but, for that kind of inquiry to be possible, we need to disaggregate the concept of 'liberalization' and explore each of its dimensions.

Second, even measures to 'liberalize' a single sphere of the political economy do not all have the same effects. Consider the reform of corporate governance. Steps to protect minority shareholders, to encourage international accounting 
standards, to promote independent directors, to unwind cross-shareholdings and to allow hostile mergers and acquisitions are all often described as elements of a single 'liberalization' process that is undermining 'coordinated market economies'. But the impact of each of these measures on the ways firms coordinate is different. Some analysts seem to assume that any step in this direction will substantially enhance the power of shareholders vis-à-vis stakeholders and corrode the potential for strategic coordination. However, we see few reasons why the adoption of international accounting standards, independent directors and better protection for minority shareholders should damage the corporate networks that condition the provision of capital in such nations, let alone dictate changes in labour relations. Conversely, if hostile takeovers were to become a prominent feature of such economies, investors would have a way of enforcing their concerns about 'shareholder value' on managers, who might be impelled to unwind some of the cooperative arrangements with other stakeholders on which modes of strategic coordination depend. To treat all of these measures as part of a single process of 'liberalization' inadvertently disguises differences in their impact.

Third, if our analysis is correct, the economic impact of many institutional reforms should be dependent on the structure of other institutional arrangements in that economy. There is evidence, for instance, that the economic effects of reforms to corporate governance depend on the character of labour relations (Hall and Gingerich, 2004). A number of studies have suggested that the impact of making the central bank more independent of political control will hinge on the character of the national wage bargaining system (Iversen, 1999; Hall and Franzese, 1998). Even when identical institutional reforms are being examined, to assume they will have identical effects in all nations is a mistake. Because of institutional interaction effects, the impact may vary dramatically.

Without denying that the concept of 'liberalization' has an important political reality associated with the 'move to the market' begun in the era of Reagan and Thatcher, we question its value for diagnosing the impact of institutional reform on the developed political economies. Britain and Sweden both experienced what can be called significant 'liberalization' of industrial relations during the 1980s and 1990s (Wallerstein and Golden, 1997). But liberalization in Britain was associated with the decline of unions and employers associations, effectively dismantling some kinds of coordinating capacities. In Sweden, in contrast, liberalization involved a movement away from national-level wage coordination, accompanied by a cross-class realignment that brought much closer coordination between blue and white collar bargaining within the export sector, while leaving the public sector to bargain separately (Thelen and Kume, 2006). Not all changes grouped together under the rubric of 'liberalization' produce meaningful 'convergence' between coordinated and liberal market economies. To make sense of such 
developments, we need alternative categories with which to secure more fine-grained assessments of the impact of institutional change.

To frame the debate in terms of an undifferentiated view of 'liberalization' squanders one of the principal advancements offered by the varietiesof-capitalism framework. The corporatist literature of the 1970s and 1980s often arrayed countries along a single continuum, portraying differences between them as differences in degree (i.e. as 'more' versus 'less' corporatist; Thelen, 1994). In contrast, the varieties-of-capitalism framework recasts the debate, organizing the analysis of political economies around ideal-typical models that operate according to different logics. In other words, the differences among them are in kind rather than degree. Many current analyses of liberalization effectively re-situate countries on a single continuum, thereby reducing the issue of change to one about movement along that single continuum.

By now an impressive body of research demonstrates that, even after two decades of liberalization, a substantial gap remains between the coordinated and liberal market economies (Hall and Gingerich, 2004, Table 8; Hall, 2007). Despite increases in part-time and/or temporary employment, and declines in unemployment benefits, employment protection and union membership, the most generous welfare states remain the most generous (Garfinkel et al., 2007). Countries where firms have traditionally relied on specific, as opposed to general, skills continue to do so (Campbell et al., 2006; Estevez-Abe et al., 2001). Although wages are now rarely coordinated at the peak level and sectoral wage coordination is looser than 20 years ago, there is still extensive wage coordination in coordinated market economies (Hassel and Williamson, 2004). More dramatic changes are visible in the areas of corporate governance and finance, although, even there, moves to liberalize have provoked resistance (Callaghan, 2004; Guillen, 2000).

\subsection{The nature and direction of change}

The observation that contemporary changes have not erased the core distinction between liberal market economies and coordinated market economies does not imply, however, that the changes currently underway are insignificant. As a first step towards assessing that significance, we need to distinguish between particular sets of institutional arrangements present in the political economy and the type of coordination they sustain. Critics of varieties of capitalism sometimes view any changes in formal institutions as a sign of changes in coordinating capacities. As we have indicated, however, some institutional changes erode those capacities, while others may simply shore them up.

However, the breadth of the categories of 'market' and 'strategic' coordination can mask changes in the quality of the equilibria secured under each modality. 
This suggests the need to build out from the core dichotomy on which the original varieties-of-capitalism framework rests to more nuanced analyses of what might be described as non-trivial movement within the broad categories of 'coordinated' and 'liberal' market economies (see e.g. Hoepner, 2007; Amable, 2003; Swank et al., 2008). In Germany, for example, the reforms made in a number of realms, including industrial relations, vocational training and social policy, do not signal a shift to the Anglo-Saxon model so much as they point to the development of new forms of dualism and labour market segmentation. These are characteristics associated in the past with what the original varieties-of-capitalism volume identified as an alternative version of 'groupbased' coordination, present, for example, in Japan (Hall and Soskice, 2001, pp. 33-36). The narrowing of collective bargaining coverage, the closure of internal labour markets especially in large companies, the trend towards more enterprise-oriented modes of in-plant training, and welfare state reforms that sharpen the divide between labour market insiders and outsiders represent important developments in the mode of coordination, even if they do not signal its collapse (Thelen and Kume, 2006).

The emphasis of the varieties-of-capitalism framework on the systemic features of the political economy provides crucial tools for understanding the impact and direction of change. It draws our attention, for instance, to the relationship between cooperation involving labour and capital at the firm level (as between works councils and employers in large firms) and the state of coordination at the national-political level (Thelen and van Wijnbergen, 2003). Developments in this relationship are not well captured on a simple liberalization continuum, although it is also clear that analysing their causes and consequences will require the development of more differentiated categories than the simple but powerful dichotomy between strategic and market coordination.

In developing such categories, our perspective suggests promise in focusing on the political coalitions that support the institutional arrangements underpinning the coordination. Influenced by the varieties-of-capitalism perspective, a promising literature in comparative political economy is beginning to link institutional analysis to coalitional analysis (Iversen and Soskice, 2007; Gourevitch and Shinn, 2005; Thelen, 2004; Mares, 2003; Huber and Stephens, 2001; Swenson, 2002). Much of it traces the genesis of important institutional configurations to specific sets of coalitions, formed either among producer groups or within the electoral arena, many of them cross-class coalitions. ${ }^{10}$

\footnotetext{
${ }^{10}$ For a review of the co-evolution of the literatures on varieties of capitalism and cross-class alliances, see Thelen (2002).
} 
A related set of analyses explains changes in the form or function of institutions over time by reference to shifts in the coalitional politics on which they rest (Iversen, 1999; Thelen, 2004). These analyses suggest that important distinctions among liberal and coordinated market economies, bearing on the resilience of coordination in each and on the distribution of its benefits, can be based on variation in the sources of political support for the types of coordination they display (see also Pontusson, 2005). Such studies have also begun to explain the resiliency of more solidaristic forms of coordination, even as they provide insights into why other countries drift towards more decentralized, segmentalist forms of coordination (Martin and Thelen, 2007; Palier and Thelen, 2008). In sum, the kind of coalitional analysis that has been so important for explaining the origins of many institutions in coordinated market economies also provides the basis for a dynamic account of how shifting alignments of interests bring about the reconfiguration of institutions and forms of coordination in both liberal and coordinated market economies.

Not all of the important changes in Europe, however, reflect re-negotiations of coordination: it is also possible for strategic coordination to give way to market coordination. The 'mixed market economies' of Southern Europe provide a set of cases where this kind of outcome is in prospect, against which our perspectives can be assessed (Hall and Gingerich, 2004). Historically, these political economies have been characterized by high levels of strategic coordination in corporate governance and labour relations, but coordination secured largely by the actions of relatively interventionist states (Schmidt, 2002). Therefore, they are hard cases, in particular, for our proposition that institutional change is led as often 'from below' as 'from above'.

France is the paradigmatic case. There, large-scale change in the political economy was initiated by a series of governmental decisions to forsake dirigiste policies in favour of market-oriented coordination, beginning in 1983 (Hall, 1987). By virtue of the prominent role its state played in strategic coordination, France was peculiarly vulnerable to the disillusionment with state intervention that followed the economic crises of the 1970s and the institutional transformation of its political economy, more profound than elsewhere in Europe. As Culpepper (2006) has observed, however, once given a freer hand, French firms led the movement that was to move corporate governance and industrial relations in the private sector in market-oriented directions. Large firms took responsibility for devising new modes of inter-corporate coordination to replace those that had once been operated by the state (Hancke, 2002). In short, although the endpoint was more dramatic, on close inspection, France displays a politics of institutional change involving initiatives from above and below, marked by various kinds of mobilization and experimentation, that corresponds to the model presented here (Culpepper et al., 2006). 


\section{Conclusion}

The objective of this paper is to elaborate the perspective on institutional change we associate with a varieties-of-capitalism approach to the political economy. We have tried to show that an approach that understands institutions at least partly in equilibrium terms can accommodate an analysis of institutional change, and that a broadly rationalist approach can comprehend many of the subtle features of such processes of change. We have emphasized that, even when institutions are Pareto-improving in the context of strategic interaction, their stability should not be taken for granted because it rests on a highly political process of mobilization marked by conflict and experimentation through which informational issues are resolved and distributional issues contested.

We have portrayed the political economy as an institutional ecology in which the strategies of the actors are simultaneously conditioned by multiple institutions, and the process of institutional change is one of mutual adjustment, inflected by distributive concerns, with incremental impacts on the strategies of firms and other actors. The model we propose acknowledges more change than analyses focused entirely on regulatory regimes or public policy normally recognize. Because we see firms as initiators of institutional change, virtually as important as the state and highly responsive to shifts in the economic environment, we observe a widespread transformation of the European political economies that is only partly reflected in policy regimes. Alongside familiar processes of reform, we see processes of defection and reinterpretation that are shifting institutional practices 'from below'. In some respects, these are simply extensions of the processes of institutional experimentation that are a regular feature of political economies, though we have also noted how incremental changes of this sort can result in major transformations over the medium and long run (Streeck and Thelen, 2005).

We have elaborated several ways of moving beyond the current fixation on the 'liberalization' of the European political economies and suggest that the most promising way to extend the varieties of capitalism perspective is to devote more attention to the types of political coalitions supporting the principal institutions of the political economy, with a view to exploring how institutional arrangements in one sphere of the political economy condition perceptions of interest and the coalitions that form around institutional reform in other spheres. That yields an account of institutional change that is eminently political.

Moreover, precisely because we see institutions in equilibrium terms, we see institutional change as more than a matter of producer group politics. Although the interests of firms and workers are crucial to particular modes of coordination, capacities for coordination also depend on a sociological underlay, subsumed in many analyses under the rubric of 'common knowledge'. As a set of shared 
understandings about how other actors will behave under a variety of circumstances, this common knowledge extends to conceptions of social justice, about what one can reasonably expect from others, which are crucial to resolving the distributive conflicts that arise when actors try to coordinate (Rothstein, 2005; Streeck, 1997; Goldthorpe, 1978).

Such conceptions are features of the polity as a whole and potentially the Achilles heel of the European political economies. If workers no longer believe that the industrial relations system or social regimes within which they labour will deliver a just set of rewards, a nation's capacities for coordination may be threatened, even if its institutions remain intact; and it is here that the most serious question marks hang over the European political economies. In the face of a changing economy, as firms and governments decide how to reallocate work, benefits and leisure, and what to demand of those who receive them, the settled expectations of the post-war decades are being called into question. These issues render developments in the realm of electoral politics salient to the effectiveness of coordination in the political economy, and they too will have to figure in on-going analyses of institutional change.

\section{Acknowledgements}

The authors are grateful to Sabina Avdagic, John Campbell, Richard Deeg, Henry Farrell, Martin Höpner and Jonathan Zeitlin for their comments on earlier versions of this article.

\section{References}

Amable, B. (2003) The Diversity of Modern Capitalism, Oxford, Oxford University Press. Aoki, M. (2001) Toward a Comparative Institutional Analysis, Cambridge, MA, MIT Press.

Bates, R. (1988) 'Contra Contractarianism: Some Reflections on the New Institutionalism', Politics and Society, 16, 387-401.

Blyth, M. (2003) 'Same as It Never Was: Temporality and Typology in the Varieties of Capitalism', Comparative European Politics, 1, 215-225.

Boyer, R. (1990) The Regulation School: A Critical Introduction, New York, Columbia University Press.

Cable, V. (1995) 'The Diminished Nation-State: A Study in the Loss of Economic Power', Daedalus, 124, 23-54.

Callaghan, H. (2004) 'The Domestic Politics of EU Legislation: British, French and German Attitudes towards Takeover Regulation, 1985-2003'. In Paper Presented to the Conference of Europeanists, March. 
Calvert, R. (1995a) 'Rational Actors, Equilibrium and Institutions'. In Knight, J. and Sened, I. (eds) Explaining Social Institutions, Ann Arbor, MI, University of Michigan Press, pp. 57-94.

Calvert, R. (1995b) 'The Rational Choice Theory of Institutions: Cooperation, Coordination and Communication'. In Banks, J. S. and Hanuschek, E. A. (eds) Modern Political Economy, New York, Cambridge University Press, pp. 216-268.

Campbell, J. L. (2004) Institutional Change and Globalization, Princeton, NJ, Princeton University Press.

Campbell, J. L., Hall, J. A. and Pedersen, O. K. (2006) The State of Denmark, Montreal, McGill University Press.

Coates, D. (ed) (2005) Varieties of Capitalism, Varieties of Approaches, Hampshire, UK, Palgrave-Macmillan.

Crouch, C. (2005) Capitalist Diversity and Change: Recombinant Governance and Institutional Pioneers, Oxford, Oxford University Press.

Culpepper, P. D. (2003) Creating Cooperation: How States Develop Human Capital in Europe, Ithaca, NY, Cornell University Press.

Culpepper, P. D. (2005) 'Institutional Change in Contemporary Capitalism: Coordinated Financial Systems since 1990', World Politics, 57, 173-199.

Culpepper, P., Hall, P. A. and Palier, B. (eds) (2006) Changing France: The Politics that Markets Make, London, Palgrave-Macmillan.

Djelic, M.-L. and Quack, S. (2003) Globalization and Institutions: Redefining the Rules of the Economic Game, Cheltenham, UK, Edward Elgar.

Dobbin, F. (1994) 'Cultural Models of Organization: The Social Construction of Rational Organizing Principles'. In Crane, D. (ed) The Sociology of Culture, Oxford, Blackwell, pp. 117-191.

Estevez-Abe, M., Iversen, T. and Soskice, D. (2001) 'Social Protection and the Formation of Skills: A Reinterpretation of the Welfare State'. In Hall, P. A. and Soskice, D. (eds) Varieties of Capitalism, Oxford, Oxford University Press, pp. 145-183.

Evans, A. (2005) 'Preemptive Modernisation and the Politics of Sectoral Defense: Adjustment to Globalisation in the Portuguese Pharmacy Sector', Comparative Politics, 40, 253-272.

Frieden, J. and Rogowski, R. (1996) 'The Impact of the International Economy on National Policies: An Analytical Overview'. In Keohane, R. O. and Milner, H. V. (eds) Internationalization and Domestic Politics, New York, Cambridge University Press, pp. 108-136.

Garfinkel, I., Rainwater, L. and Smeeding, T. (2007) The American Welfare State: Laggard or Leader? New York, Russell Sage Foundation.

Glyn, A. (2006) Capitalism Unleashed, Oxford, Oxford University Press.

Goldthorpe, J. H. (1978) 'The Current Inflation: Towards a Sociological Account'. In Hirsch, F. and Goldthorpe, J. H. (eds) The Political Economy of Inflation, Cambridge, MA, Harvard University Press, pp. 186-214. 
Goodin, R. (2003) 'Choose Your Capitalism?', Comparative European Politics, 1, 203-213. Gourevitch, P. A. and Shinn, J. (2005) Political Power and Corporate Control: The New Global Politics of Corporate Governance, Princeton, NJ, Princeton University Press.

Goyer, M. (2006) 'The Transformation of Corporate Governance in France'. In Culpepper, P., Hall, P. A. and Palier, B. (eds) Changing France: The Politics that Markets Make, London, Palgrave-Macmillan, pp. 80-104.

Goyer, M. (2007) 'Capital Mobility, Varieties of Institutional Investors and the Transforming Stability of Corporate Governance in France and Germany'. In Hancké, B., Rhodes, M. and Thatcher, M. (eds) Beyond Varieties of Capitalism: Conflict, Contradictions and Complementarities in the European Economy, Oxford, Oxford University Press, pp. 195-222.

Greif, A. and Laitin, D. (2004) 'A Theory of Endogenous Institutional Change', American Political Science Review, 98, 633-652.

Gruber, L. (2000) Ruling the World: Power Politics and the Rise of Supranational Institutions, Princeton, NJ, Princeton University Press.

Guillen, M. (2000) 'Corporate Governance and Globalization: Is There Convergence Across Countries?', Advances in International Comparative Management, 13, 175-204.

Hacker, J. (2005) 'Policy Drift: The Hidden Politics of US Welfare State Retrenchment'. In Streeck, W. and Thelen, K. (eds) Beyond Continuity: Institutional Change in Advanced Political Economies, Oxford, Oxford University Press, pp. 40-82.

Hall, P. A. (1987) 'The Evolution of Economic Policy under Mitterrand'. In Ross, G., Hoffmann, S. and Malzacher, S. (eds) The Mitterrand Experiment: Continuity and Change in Modern France, New York, Oxford University Press, pp. 54-72.

Hall, P. A. (1994) 'Central Bank Independence and Coordinated Wage Bargaining: Their Interaction in Germany and Europe', German Politics and Society, 31, 1-23.

Hall, P. A. (1998) 'Institutions and Economic Performance: The Evolution of the Field from the Perspective of Political Science'. In Lecture to the GAAC Workshop on Institutions and Economic Performance in Advanced Economies since 1945, Wissenschaftszentrum, Berlin, July.

Hall, P. A. (2000) 'Organized Market Economies and Unemployment in Europe: Is it Finally Time to Accept Liberal Orthodoxy?' In Bermeo, N. (ed) Context and Consequence: The Effects of Unemployment in the New Europe, New York, Cambridge University Press.

Hall, P. A. (2005) 'Preference Formation as a Political Process: The Case of Monetary Union in Europe'. In Katznelson, I. and Weingast, B. (eds) Preferences and Situations, New York, Russell Sage Foundation, pp. 129-160.

Hall, P. A. (2007) 'The Evolution of Varieties of Capitalism in Europe'. In Hancké, B., Rhodes, M. and Thatcher, M. (eds) Beyond Varieties of Capitalism: Conflict, Contradictions and Complementarities in the European Economy, Oxford, Oxford University Press, pp. $39-88$. 
Hall, P. A. and Franzese, R. Jr. (1998) 'Mixed Signals: Central Bank Independence, Coordinated Wage Bargaining, and European Monetary Union', International Organisation, 52, 502-536.

Hall, P. A. and Gingerich, D. (2004) Varieties of Capitalism and Institutional Complementarities in the Macro-Economy, Discussion Paper 04/5, Cologne, Max Planck Institute for the Study of Societies.

Hall, P. A. and Soskice, D. (eds) (2001) Varieties of Capitalism: The Institutional Foundations of Comparative Advantage, Oxford, Oxford University Press.

Hancké, B. (2001) 'Revisiting the French Model: Coordination and Restructuring in French Industry'. In Hall, P. A. and Soskice, D. (eds) Varieties of Capitalism: The Institutional Foundations of Comparative Advantage, Oxford, Oxford University Press, pp. 307-334.

Hancké, B. (2002) Large Firms and Institutional Change: Industrial Renewal and Economic Restructuring in France, Oxford, Oxford University Press.

Hassel, A. and Williamson, H. (2004) 'The Evolution of the German Model: How to Judge the Reforms in Europe's Largest Economy'. In Paper Prepared for the Anglo-German Foundation for the Study of Industrial Society.

Hoepner, M. (2001) Corporate Governance in Transition: Ten Empirical Findings on Shareholder Value and Industrial Relations in Germany, Discussion Paper 01/5, Cologne, Max Planck Institute for the Study of Societies.

Hoepner, M. (2003) European Corporate Governance Reform and the German Party Paradox, Discussion Paper 03/4, Cologne, Max Planck Institute for the Study of Societies.

Hoepner, M. (2007) Coordination and Organization: The Two Dimensions of Nonliberal Capitalism, Discussion Paper 07/12, Cologne, Max Planck Institute for the Study of Societies.

Howell, C. (2003) 'Varieties of Capitalism: and Then There Was One?', Comparative Politics, 36, 102-124.

Huber, E. and Stephens, J. D. (2001) Development and Crisis of the Welfare State: Parties and Policies in Global Markets, Chicago, University of Chicago Press.

Iversen, T. (1999) Contested Institutions, New York, Cambridge University Press.

Iversen, T. and Soskice, D. (2007) Distribution and Redistribution: The Shadow from the Nineteenth Century, Working Paper, Department of Government, Harvard University.

Iversen, T. and Wren, A. (1998) 'Equality, Employment and Budgetary Restraint', World Politics, 50, 507-546.

Knight, J. (1992) Institutions and Social Conflict, New York, Cambridge University Press.

Knight, J. (1995) 'Models, Interpretation and Theories: Constructing Explanations of Institutional Emergence and Change'. In Knight, J. and Sened, I. (eds) Explaining Social Institutions, Ann Arbor, MI, University of Michigan Press, pp. 95-120. 
Manow, P. and Seils, E. (2000) 'Adjusting Badly: The German Welfare State, Structural Change and the Open Economy'. In Scharpf, F. and Schmidt, V. (eds) Welfare and Work in the Open Economy, Oxford, Oxford University Press, pp. 264-307.

March, J. G. and Olsen, J. P. (1989) Rediscovering Institutions: The Organizational Basis of Politics, New York, Free Press.

Mares, I. (2003) The Politics of Social Risk, New York, Cambridge University Press.

Martin, C. J. and Thelen, K. (2007) 'The State and Coordinated Capitalism: Contributions of the Public Sector to Social Solidarity in Post-Industrial Societies', World Politics, 60, $1-36$.

Milgrom, P. and Roberts, J. (1992) Economics, Organization and Management, Englewood Cliffs, NJ, Prentice Hall.

Moe, T. (2005) 'Power and Political Institutions', Perspectives on Politics, 3, 215-234.

Offe, C. and Wiesenthal, H. (1986) 'Two Logics of Collective Action: Theoretical Notes on Social Class and Political Form'. In Offe, C. (ed) Disorganized Capitalism, Cambridge, MA, MIT Press, pp. 170-220.

O'Sullivan, M. (2007) 'Acting Out Institutional Change: Understanding the Recent Transformation of the French Financial System', Socio-Economic Review, 5, 389-436.

Palier, B. (2005) 'Ambiguous Agreement, Cumulative Change: French Social Policy in the 1990s'. In Streeck, W. and Thelen, K. (eds) Beyond Continuity: Institutional Change in Advanced Political Economies, Oxford, Oxford University Press, pp. 127-144.

Palier, B. and Thelen, K. (2008) 'Dualizing CMEs: Flexibility and Change in Coordinated Market Economies'. In Presented at the 16th Conference of the Council for European Studies, 6-8 March 2008, Chicago.

Pierson, P. (1993) 'When Effect Becomes Cause: Policy Feedback and Political Change', World Politics, 45, pp. 595-628.

Pierson, P. (1994) Dismantling the Welfare State? Reagan, Thatcher, and the Politics of Retrenchment, New York, Cambridge University Press.

Pierson, P. (ed) (2001) The New Politics of the Welfare State, New York, Oxford University Press.

Pontusson, J. (2005) 'Varieties and Commonalities of Capitalism'. In Coates, D. (ed) Varieties of Capitalism, Varieties of Approaches, Hampshire, UK, Palgrave-Macmillan, pp. $163-188$.

Pontusson, J. and Swenson, P. (1996) 'Labor Markets, Production Strategies and Wage Bargaining Institutions', Comparative Political Studies, 29, 223-250.

Rehder, B. (2006) 'Legitimitätsdefizite des Co-Managements. Betriebliche Bündnisse als Konfliktfeld zwischen Arbeitnehmern und betrieblicher Interessenvertretung', Zeitschrift für Soziologie, 35, 227-242.

Rieger, E. and Leibfried, S. (2003) Limits to Globalization, Oxford, Polity.

Rothstein, B. (2005) Social Traps and the Problem of Trust, Cambridge, UK, Cambridge University Press. 
Schmidt, V. (2002) The Futures of European Capitalism, Oxford, Oxford University Press. Schmitter, P. and Streeck, W. (1985) Private Interest Government, London, Sage.

Sewell, W. (2008) 'The Temporalities of Capitalism', Socio-Economic Review, 6, 517-537.

Shepsle, K. (1986) 'Institutional Equilibrium and Equilibrium Institutions'. In Weisberg, H. (ed) Political Science: The Science of Politics, New York, Agathon, pp. 51-81.

Streeck, W. (1991) 'On the Institutional Conditions for Diversified Quality Production' In Matzner, E. and Streeck, W. (eds) Beyond Keynesianism, London, Edward Elgar, pp. 21-61.

Streeck, W. (1992) Social Institutions and Economic Performance, Beverly Hills, Sage.

Streeck, W. (1997) 'The German Economic Model: Does It Exist? Can it Survive?', In Crouch, C. and Streeck, W. (eds) The Political Economy of Modern Capitalism, London, Sage, pp. 33-54.

Streeck, W. (2004) 'Taking Uncertainty Seriously: Complementarity as a Moving Target', Workshop Proceedings of the Osterreichische Nationalbank, 1, 101-115.

Streeck, W. (2005) 'Rejoinder: On Terminology, Functionalism, (Historical) Institutionalism and Liberalism', Socio-Economic Review, 3, 577-587.

Streeck, W. (2009, forthcoming) Re-Forming Capitalism. Institutional Change in the German Political Economy, Oxford, Oxford University Press.

Streeck, W. and Thelen, K. (eds) (2005) Beyond Continuity: Institutional Change in Advanced Political Economies, Oxford, Oxford University Press.

Swank, D., Martin, C. J. and Thelen, K. (2008) 'Institutional Change and the Politics of Social Solidarity in Advanced Industrial Democracies'. In Paper Presented at the Conference of Europeanists, Chicago, IL, March 2008.

Swenson, P. (1991) 'Bringing Capital Back In, or Social Democracy Reconsidered: Employer Power, Cross-Class Alliances and Centralization of Industrial Relations in Denmark and Sweden', World Politics, 43, 513-544.

Swenson, P. (2002) Capitalists Against Markets, New York, Oxford University Press.

Thelen, K. (1991) Union of Parts: Labor Politics in Postwar Germany, Ithaca, NY, Cornell University Press.

Thelen, K. (1994) 'Beyond Corporatism: Toward a New Framework for the Study of Labor in Advanced Capitalism', Comparative Politics, 27, 107-124.

Thelen, K. (2000) 'Why Germany Employers Cannot Bring Themselves to Dismantle the German Model'. In Iversen, T., Pontusson, J. and Soskice, D. (eds) Unions, Employers and Central Banks, New York, Cambridge University Press, pp. 138-169.

Thelen, K. (2001) 'Varieties of Labor Politics in the Developed Democracies'. In Hall, P. A. and Soskice, D. (eds) (2001) Varieties of Capitalism: The Institutional Foundations of Comparative Advantage, Oxford, Oxford University Press, pp. 71-103.

Thelen, K. (2002) 'The Political Economy of Business and Labor in the Developed Democracies: Agency and Structure in Historical-Institutional Perspective'. In 
Katznelson, I. and Milner, H. (eds) Political Science: The State of the Discipline, New York, W. W. Norton, pp. 371-397.

Thelen, K. (2004) How Institutions Evolve, New York, Cambridge University Press.

Thelen, K. and Kume, I. (1999) The Effects of Globalization on Labor Revisited: Lessons from Germany and Japan', Politics and Society, 27, 477-505.

Thelen, K. and Kume, I. (2006) 'Coordination as a Political Problem in Coordinated Market Economies', Governance, 19, 11-42.

Thelen, K. and van Wijnbergen, C. (2003) 'The Paradox of Globalization: Labor Relations in Germany and Beyond', Comparative Political Studies, 36, 859-880.

Tiberghien, Y. (2002) Political Mediation of Global Market Forces, Ph.D. Dissertation, Stanford University.

Wallerstein, M. and Golden, M. (1997) 'The Fragmentation of the Bargaining Society: Wage Setting in the Nordic Countries, 1950 to 1992', Comparative Political Studies, 30, 699-731.

Watson, M. (2003) 'Ricardian Political Economy and the Varieties of Capitalism Approach: Specialisation, Trade and Comparative Institutional Advantage', Comparative European Politics, 1, 227-240. 